\title{
WofdliticGrienReview
}

Volume 2, Issue 1

\section{Politicization in Associations: An Empirical Study of the Relationship between Membership in Associations and Participation in Political Discussions}

Emanuel von Erlach*

*Bern University, vonerlach@ipw.unibe.ch

Originally published as Emanuel von Erlach 2005. "Politisierung in Vereinen. Eine empirische Studie zum Zusammenhang zwischen der Vereinsmitgliedschaftund der Teilnahme an politischen Diskussionen." Schweizerische Zeitschrift für Politikwissenschaft 11(3): 27-59. Reprinted with permission from Schweizerische Zeitschrift für Politikwissenschaft. 
von Erlach: Politicization in Associations

\title{
*Politicization in Associations. An empirical study of the relationship between membership in associations and participation in political discussions
}

\author{
Emanuel von Erlach \\ Institute Of Political Science, University Of Bern
}

\begin{abstract}
Empirical studies clearly show that not only are members of associations more politically active than non-members, but they also take a greater interest in politics and participate more often in political debate. Based on analyses of the correlation between association membership and participation in political discussions, the following article shows that these empirical findings are attributable only in limited measure to the political socialization effects of voluntary organizations. The results of multivariate analyses suggest that it is not so much association membership as early political socialization and education that lead to greater participation in political discussions. Associations do have a politicizing effect, however, chiefly when they afford an opportunity for their members to learn or cultivate organizational and communication skills or the ability to deal with conflict.
\end{abstract}

\section{Introduction 1}

The close of the previous millennium saw the ascendancy of theories and approaches stressing social connectedness as essential to the functioning and survival of modern societies. In particular, they underscore the edifying effects

\footnotetext{
* Originally published as Emanuel von Erlach 2005. "Politisierung in Vereinen. Eine empirische Studie zum Zusammenhang zwischen der Vereinsmitgliedschaftund der Teilnahme an politischen Diskussionen." Schweizerische Zeitschrift für Politikwissenschaft 11(3): 27-59.

${ }^{1}$ This article was written within the framework of a project funded by the Swiss National Science foundation on the connection between social integration and political involvement (No. 1214-057261). I would like to thank André Bächtiger, Thomas E. Henökl and the two anonymous evaluators as well as the publishers of Swiss Political Science Review for their helpful criticism and suggestions. Many thanks go to Eric Rosencrantz for translating this article from German into English.
} 
of clubs, associations and other group forms of civic engagement. Suchlike voluntary organizations are seen as social structures that generate and impart fundamental norms and values of co-existence and cooperation (Putnam 1993a; $\mathrm{b}$; 2000) and provide a forum for the development of organizational and communication skills as well as self-confidence (Verba et al. 1995; Ayala 2000), thereby fostering a large measure of individual development and selfrealization (Evans and Boyte 1992). In the course of association activities, individuals are said to learn to trust others, to discern shared interests through confrontation with the opinions and problems of others, to develop a sense of cohesion and, in addition to a self-centered perspective, to adopt one of group solidarity as well. This creates the conditions necessary to help overcome dilemmas inherent in collective action (cf. e.g. Coleman 1990; Putnam 1993a; 2000).

For these reasons, and because they provide structures that can be used for political mobilization and recruitment, voluntary organizations are regarded as infrastructures of civil society. They are seen as mainstays and disseminators of a participatory democratic culture, as guarantees of a politically engaged and active citizenry, or in general as schools of democracy (cf. Putnam 1993a, 2000, Kunz and Gabriel 2000). In other words, voluntary organizations are expected to turn out politically engaged citizens from among the ranks of their members.

That people who are members of voluntary organizations are indeed more politically engaged than those who aren't has been shown in any number of empirical studies for many different societies and at various times over the last fifty years (c.f. van Deth 1997; 2001). But in spite of the many existing studies on the subject, the reasons for the disparity in political behavior between association members and non-members remain unclear: is it because voluntary organizations exert a politicizing influence on their members or because the politically involved are naturally more inclined to join such organizations than the politically apathetic are?

In most fieldwork, association membership is measured in fairly rough terms (e.g. members versus non-members or number of association memberships) and analyzed along the same lines as other socio-structural variables like age or sex. Empirically, at any rate, the process responsible for any correlations found is treated as a black box. Only the control variables used can be ruled out as causing the difference in political involvement between association members and non-members.

The present study aims to explore this gap in the research by asking: Which aspects of association membership foster or inhibit political involvement? The question is addressed by looking at one manifestation of politicization: viz. frequency of participation in political discussions. The empirical black box around the nexus between membership in associations and political engagement is at least partially opened here by specifically investigating the degree to which the frequency of participation in discussions of political subjects is influenced by the following factors: active membership in various types of associations, the amount of time spent on association activities, the exercise of organizational and communication skills in an associational setting, 
von Erlach: Politicization in Associations

the degree of integration into an association, carrying on conflicts within associations, and membership-related cross pressures.

\section{Theoretical arguments for the politicizing effects of associations}

In the following we present the main theoretical arguments adduced to explain the link between membership in voluntary organizations and political involvement. Most of these hypotheses have been formulated to account for the influence of association membership on interest or participation in politics. They can also be applied, however, to the frequency of participation in political discussions.

Three principal mechanisms may be adduced to account for the positive correlation between association membership and political involvement:

1. Politicization through political recruitment and mobilization in voluntary organizations: Voluntary organizations play an important political role in real modern democracies. Clubs, associations and other group forms of civic engagement are politically significant because political interests form and fuse therein, because these organizations represent group demands in political decision-making processes, because (depending on the configuration of the political system in question) they are involved in the implementation of policies, and not least because through them political élites can touch base with their grass-roots constituencies (cf. van Deth 1997: 3 ff; Rothenberg 1992: 6). These various functions are performed not only by political organizations, but also by otherwise apolitical ones. "[V]oluntary associations must at least on occasion participate in the political system, influencing political leaders and decision making, as well as giving political élites a channel for contacting constituents. In this view, many associations that are normally non-political can temporarily become 'parapolitical' actors" (Olsen 1972:318). In other words, associations serve as potential social infrastructures for political action, as a framework for political mobilization and recruitment. Members can be directly incited to take part in political activities by the executive committee or other members of their association (see e.g. Olsen 1974; Pollok 1982; Leighley 1996; Teorell 2003).

2. Politicization through access to and acquisition of resources via voluntary associations: Generally speaking, social networks constitute easily accessible sources of politically pertinent information (La Due Lake and Huckfeldt 1998). This is especially true of networks formed within the framework of voluntary organizations. Many associations collect, process and disseminate information to acquaint members with matters of relevance to them, and an association can collectively process far more, and far more complex, information than a solitary individual can. Information is a key political resource: it empowers citizens to demand transparency and accountability from state institutions as from other powerful players in society (e.g. corporations) (cf. e.g. Warren 2001: 71). Associations enable individual 
members to reduce considerably the cost of obtaining information they need for political participation and to benefit from the political expertise of others, whether in the form of association publications, talks at association events or informal political exchanges with co-members (Warren 2001; Putnam 2000; Gabriel et al. 2002). Further, activities and honorary offices in voluntary organizations afford an opportunity to acquire and hone skills that facilitate the performance of political acts (see e.g. Verba et al. 1995; Brady et al. 1995; Ayala 2000).

3. Politicization through the adoption of political standpoints and orientations in the course of association membership: By taking part in association activities, members may develop standpoints, norms and values, or adopt those of their peers, that conduce to political involvement. We can expect successful actions in or with voluntary organizations to boost an individual participant's self-confidence. Individuals thereby experience the power of collective action and develop a sense of having an impact on society or politics, which can boost their interest in politics and their motivation to participate in the political process. Tocqueville made this point as far back as the early $19^{\text {th }}$ century in his works on American democracy: "Des citoyens individuellement faibles ne se font pas d'avance une idée claire de la force qu'ils peuvent acquérir en s'unissant. [...]. En politique, les hommes s'unissent pour de grandes entreprises, et le parti qu'ils tirent de l'association dans les affaires importantes leur enseigne, d'une manière pratique, l'intérêt qu'ils ont à s'en aider dans les moindres" (Tocqueville 1961 [1840]: 167).

The confrontation with others, moreover, is apt to broaden one's horizons, which may then nurture an interest in the workings of society and politics and heighten civic consciousness. In addition, association members may adopt participatory norms and values under a more or less latent form of peer pressure. Another possibility is the formation of a group identity and the consolidation of ideological standpoints, both of which may foster political involvement (see e.g. Pollok 1982; Erickson and Nosanchuck 1990; van Deth 1997; Gabriel et al. 2002).

The same politicizing potential cannot be ascribed to every type of membership. Association members are most likely to acquire skills facilitating political participation, form social networks with fellow members, or adopt attitudes conducive to political involvement if they take an active part in association life and interact directly with other members (Erickson and Nosanchuck 1990). But the possibility that passive members also get politicized should not be rejected out of hand. They may become politically informed through association publications and may be subject to (written) attempts at political recruitment and mobilization (cf. Wollebaek and Selle 2003).

Through membership, however, passive members who never take part in association activities will not acquire skills facilitating political participation (particularly the organizational and communication skills emphasized by Verba et al. 1995) or additional political information in political discussions with 
other members; nor will they boost their self-assurance to the same extent as active members through collective achievements. They will not be subject, moreover, to political mobilization and recruitment efforts made by other members, or any related pressure to take part in political activities that take place during or following association activities.

Wollebaek and Selle (2003:86) argue, on the other hand, that passive members may very well keep in touch with active members outside the associational setting and, as a result, may likewise be subject to attempts at political mobilization and recruitment. But to what extent is such politicization then attributable to membership in a voluntary organization? If the acquaintance between active and passive members predates membership (how is a passive member to meet active ones if he does not take part in association activities?), then the politicizing effect is not primarily due to membership, but to integration into a pre-existing circle of friends. On the whole, empirical findings suggest that active members are in fact more politically engaged than passive ones (cf. e.g. Maccoby 1958; Leighley 1996; Moyser and Geraint 1997; van Deth 1996; Kunz and Gabriel 2000; Miller 2001).

Nor should it be assumed, as a rule, that all types of association are equally capable of kindling political involvement. To be sure, indirect mobilization may result from the attainment of skills or the influence of socialization and integration on political attitudes in any association that permits active participation in its activities. It is theoretically plausible to assert that any voluntary organization can make direct efforts to politically mobilize its members and can potentially act as an interest group (cf. e.g. Olsen 1972). Moreover, regardless of the nature of the association, its structures can be used by political players to disseminate political information (or propaganda) or for mobilization purposes (see in particular Coleman 1990). But it can be assumed a voluntary association will politically inform its members and mobilize them to take part in political activities chiefly when it is a matter of defending the association's own interests in political decision-making processes - which, depending on the objects of the association, may very rarely be the case. Furthermore, given the potential heterogeneity of their members' political opinions, one would expect many a voluntary organization to avoid laying itself open to political criticism, as any explicit political utterance by the executive committee can cause dissenters to leave. Steiner (1969) observed in his studies, for instance: "Some associations strictly adhere to [...] political neutrality and even revile political debate for fear of causing tension within the association" (Steiner 1969:2).

Based on these considerations (and empirical findings), membership in expressive organizations can be expected to have less of an influence on political involvement than in instrumental organizations, because in the former members will be less frequently exposed to stimuli inciting to participation and political activity than in the latter. McMiller (2000: 86) distinguishes between expressive and instrumental organizations as follows: "Instrumental groups tend to focus on objectives that lie outside of the groups themselves. Because it was formed to maintain or change some normative condition in the community or larger society, instrumental groups routinely pursue political objectives. 
Conversely, expressive group activities tend to be confined and self-contained within the organization itself. Because the basic orientation of these groups is directed toward goals that contribute to the organized flow of immediate and continuing gratification, expressive groups will routinely avoid politics unless involvement can enhance the value of being affiliated with the group" (see also Gordon and Segura 1997; Jacoby and Babchuk 1963).

The distinction between instrumental and expressive voluntary organizations has already been successfully employed in other studies (i.e. the empirical findings bear out the theoretical predictions, cf. in particular Jacoby 1965; London 1975; Rogers et al. 1975; Rogers and Bultena 1975; Hanks 1981; McMiller 2000). The results of studies using other associational typologies can also be interpreted within the framework of this distinction. Members of such instrumental organizations as interest groups, social movement organizations (especially environmental associations) or political organizations are, according to empirical studies, more politically engaged than members of sports clubs and other recreational groups, which can be regarded as expressive groups (cf. Gabriel et al. 2002).

The literature usually foregrounds the politicizing effects of voluntary organizations. However, there also exist theoretical arguments on the basis of which to expect a negative correlation between association membership and political involvement (van Deth 1996; 1997; 2000). First of all, there is no guaranteeing that participatory norms and values will actually prevail in associations. Group peer pressure might just as well lead members to scoff at politics as something annoying and tedious, and at certain kinds of political participation as aberrant, undesirable behavior (see e.g. Gabriel et al. 2002). Secondly, political involvement can potentially be inhibited by "cross pressures": in theory, at least, the confrontation with political opinions that do not accord with one's own can give rise to mutually opposing forces (i.e. cross pressures), fostering political apathy rather than political involvement (see e.g. Mutz 2002; Huckfeldt et al. 2001). Thirdly, since politics is conflictual by nature, those who are wary of confrontation can be more expected to refrain from participating in political discussions as part of an individual or collective strategy of conflict avoidance (Ulbig and Funk 1999). This would neutralize the potentially politicizing effects of voluntary organizations on those members who are wary of confrontation.

Some claim, moreover, that the connection between association membership and political involvement is a pseudo-correlation. In certain circumstances, association membership and political involvement have the same socio-structural and psychological roots, though without bearing any direct relation to each other. The possibility cannot be ruled out a priori that, given their socio-structural and psychological profiles, politically interested and active individuals are disproportionately inclined to join voluntary organizations (c.f. van Deth 1996; Armingeon 2004). Finally, it should be borne in mind that there may be a reciprocal relationship between association membership and political involvement. Politically engaged citizens join voluntary organizations (e.g. human rights organizations, environmental or industrial associations) in order to try actively, or at least through donations, to 
von Erlach: Politicization in Associations

bring some influence to bear on politics and society (c.f. van Deth 1997; Gabriel et al. 2002).

The nexus between voluntary organizations and various forms of political activity has been re-examined longitudinally (Hanks and Eckland 1978; Hanks 1981; Maccoby 1958) and cross-sectionally at macro level (cf. Gabriel et al. 2002; Joye and Laurant 1997; Milner 2001; van Deth 2001), micro level (cf. the summaries of research to date in van Deth 1997; 2001) and in multi-level analyses (see e.g. Bowler et al. 2003). Empirical results at micro-level are available for the US (c.f. for instance Verba et al. 1995) and Canada (Zipp and Smith 1979; Erickson and Nosanchuck 1990), Central America (Booth and Bayer Richard 1998; Seligson 1999; Nie et al. 1969a; b), South America (Klesner 2002), Japan (Ikeda 2002) and many European countries (c.f. for instance Gabriel et al. 2002; Armingeon 2004). The bulk of these studies showed that association membership had a positive impact on political involvement (in the form of psychological political involvement or of political participation) and especially on the frequency of participation in political discussions (e.g. in Olsen 1974; Hanks 1981; Parry et al. 1992; Pettersen and Rose 1996; Gundelach and Torpe 1997) ${ }^{2}$.

In spite of these numerous studies, it is still not clear which mechanisms actually stimulate members of voluntary organizations to get politically involved. There are, to be sure, studies pinpointing specific mechanisms. It has been shown, for instance, that associations foster political involvement through improved resources (Brady et al. 1995; Verba et al. 1995; Ayala 2000), integration mechanisms (Armingeon 2004), changes in political standpoints (Pollok 1982) and political recruitment by co-members (Teorell 2003).

On the other hand, there are hardly any studies that simultaneously test the various causal hypotheses for their empirical relevance (one exception is Miller 2001). In order to ascertain more exactly how and to what extent associations actually have a politicizing effect on their members, various aspects of membership that may have an influence on political involvement are operationalized separately in this study.

\section{Research Data}

The present empirical analyses are based on the "Work, Neighbourhood, Associations, and Politics" (WNAP) dataset compiled in the year 2000 for use in the SNF project "Social Integration and Political Participation". It also represents the Swiss contribution to the EFS Network comparative study "Citizenship, Involvement, Democracy" (CID). The questionnaire used for the survey was essentially put together within the CID network. The overriding question this network addresses is: "Under what social, societal, and organizational conditions does the social involvement of citizens contribute to

\footnotetext{
${ }^{2}$ However, there are also some countries (e.g. in the comparative study by Gabriel et al. 2002) and studies (Verba et al. 1995) in which no correlation is found between association membership and participation in political discussions.
} 
qualitative and quantitative improvements in contemporary democracies?"3 The dataset includes a great deal of information about involvement in associations and generally about the social integration and political involvement of the respondents. The population for this survey from the year 2000 comprises the linguistically assimilated resident adult population of Switzerland, i.e. those surveyed were 18 or older and capable of answering the questions in German, French or Italian. The survey consisted of a computeraided telephone interview (CATI) followed up by a written questionnaire ${ }^{4}$. All told 2,145 people were interviewed for half an hour and then requested to complete the questionnaire. Roughly 75 per cent of the CATI respondents filled out the questionnaire, yielding a complete data record for 1,615 respondents 5 .

\section{Variables used in the empirical model}

Based on the foregoing theoretical considerations, our study identifies six operationalizable aspects of association membership that may be expected to influence the frequency with which an individual participates in political discussions.

Type of association and degree of activity: As pointed out above, the latest research suggests that members of instrumental voluntary organizations (organizations that seek to have an influence on society, whose objects lie outside the organization itself; cf. Gordon and Babchuk 1959) can be more readily mobilized to take part in political activities than members of expressive associations (organizations whose objects lie in the activities of the organization itself, e.g. singing in a choir or playing soccer together, cf. Gordon and Babchuk 1959). In operationalizing this variable we also distinguish a third, hybrid type of association, for some associations cannot be clearly placed in either category (e.g. organizations for the handicapped, which, depending on their orientation, assume the character of self-help groups or interest groups). One would expect the politicizing potential of these voluntary organizations to lie between that of instrumental and expressive associations. For each of these three types of associations, active membership has been allowed for in the static modeling of causal connections (the exact operationalization of all the variables is elucidated in the appendix). This is because associations may be expected to have socializing effects on individuals who have direct contact with other association members. Passive members can also be called upon (particularly in writing) to participate politically. But social control or peer pressure effects are most likely to obtain in cases of actual direct social contact and interaction.

Investment of time in social participation: This variable is a proxy for the amount of time spent (per month) on association membership. The reason it is a proxy is that the figures given by respondents also include time spent in

\footnotetext{
${ }^{3}$ For more informationen about CID see: www.mzes.uni-mannheim.de/projekte/cid/.

${ }^{4}$ The sample was taken using random-random methods.

${ }^{5}$ For more informationen about the dataset see Armingeon and Erlach (2000).
} 
von Erlach: Politicization in Associations

informal groups and on caring for old and ailing acquaintances and relations. Our expectation is that the more time a person spends in an association, the more heavily he will be exposed to associational politicizing effects and the more liable he is to get involved in political discussions.

Integration in associations: We also expect to see a positive correlation between associational integration and political involvement. The more heavily an individual is integrated into associational networks, the more he will be exposed to the politicizing effects of associations. The reasoning behind this hypothesis is that greater network density and frequency of interaction will increase the likelihood of political socialization through other association members (Erickson and Nosanchuck 1990). Concretely, integration into associational networks is measured in terms of how often the respondent talks to other association members about the association's problems and objectives and how often he sees them outside of association activities.

Organizational and communication skills ("civic skills") exercised in associations: For the purposes of this study, civic skills are measured as in Verba et al. (1995) in terms of the frequency with which members engage in certain activities: viz. writing multi-page texts (apart from private correspondence), participation in internal decision-making processes, organizing or chairing meetings, and preparing or giving presentations or speeches within the framework of association activities. These activities are usually involved in exercising an honorary function in an association (e.g. on the executive committee).

Conflict avoidance in associations: This aspect of association membership with a potential impact on political involvement can also be directly deduced from theory. We assume that, as a rule, those who seldom argue or thrash out differences of opinion with other members of an association will not often discuss politics with them either. Consequently, avoiding argument with other association members is construed as an indicator of wariness of confrontation (Ulbig and Funk 1999).

Cross pressures: Similarly, we may expect cross pressures to inhibit manifest forms of political participation and discussions. Cross pressures are measured in terms of existing political differences with fellow members. We make allowance for the fact that in some cases association members simply do not know the extent to which their political opinions accord with those of other members.

The determination and operationalization of these several aspects of membership in voluntary organizations will serve at least to raise the lid on the (empirical) black box containing the mechanisms that link association membership to political involvement, and render it accessible to empirical scrutiny.

In addition to these aspects of association membership, our analyses also take some social background variables into account as control values, first and foremost among them sex and age. We expect women (owing to genderspecific socialization, more limited resources and a lower degree of integration into the working world) to be less engaged in associations and political activities than men. With regard to age, we expect to find a curvilinear 
relationship to both association membership and political engagement, i.e. we expect people of median working age to be the most heavily involved in associations and political activities (cf. van Deth and Elff 2000). The logarithmic age is worked into our analyses for the modeling of this curvilinear relationship.

As these variables of gender and age leave considerable latitude for the interpretation of the mechanisms by which they act upon civic engagement, additional variables need to be factored into the equation, in particular those regarding resources and social integration. Existing analyses of resources have shown that, first and foremost, cognitive skills (or human capital) favor political involvement (cf. Verba et al. 1995; Brady et al. 1995; La Due Lake and Huckfeldt 1998; van Deth and Elff 2000). For the purposes of this study, they are measured in terms of education (number of years of schooling) and the exercise of skills at work.

Other quantities provide information about the social integration of individuals outside of associations. Firstly, familial integration is gauged in terms of marital status (married or cohabiting vs. divorced, widowed or single). Secondly, we assessed network integration at work and in one's neighborhood (information about network integration at work and in one's neighborhood was collected using questions and indicators corresponding to those for associational integration). Thirdly, the duration of local residence is taken as an index of embeddedness in one's place of residence.

A high degree of social integration presumably favors both membership in associations and political involvement. For one thing, existing ties in the social fabric can be used to recruit association members. For another, there is no evidence that only networks under the aegis of voluntary organizations contribute to individual political socialization and consequently political involvement, especially as many people spend far more time outside than inside voluntary organizations (cf. e.g. Newton 1997). ${ }^{6}$ Accordingly, we also expect cross pressures and conflict avoidance outside of voluntary organizations to have a potentially adverse impact on political involvement. Information on both of these constructs was obtained using questions similar to those concerning associations. The data on engagement in conflict refer to both working and neighborhood life. The information is combined under the variable average conflict avoidance outside of associations: in other words, for unemployed respondents the responses are confined to avoidance of conflict with neighbors, whereas for those who are gainfully employed the index includes their statements about conflict avoidance at work as well.

The values for cross pressures have also been averaged to reflect differences of political opinion both within associations and in the contexts of family, circle of friends, neighborhood and workplace. Since categorized data were also furnished here, four different variables have been worked out:

${ }^{6}$ The politicizing effect of social integration can be grounded not only on network-based arguments, but also in broader terms on political mobilization as a result of belonging to certain sociocultural milieus (cf. Rokkan 1977; Lipset and Rokkan 1967; Bartolini and Mair 1990). 
average number of networks with no, occasional and marked differences of political opinion, and average number of networks in respect of which respondents did not know - and could therefore give no information about the political opinions of other network members. To avoid collinearity problems, the variable average number of networks with occasional differences of political opinion is not factored into the analyses. It has the highest mean and median values. In other words, most people are occasionally confronted with political opinions they do not share in most of the social circles in which they move (for similar findings see Huckfeldt et al. 2001; Huckfeldt et al. 2002).

To control for possible self-selection effects that are responsible for the link between association membership and political discussions, an index of politicization in one's youth is allowed for in the analyses, reflecting the frequency of political discussions at home during the respondent's youth. This variable obviously predates current political involvement and association memberships. In interpreting the empirical analyses, however, it must be borne in mind that statements about political discussions in one's youth can be slightly distorted: to preserve a stable, coherent self-image, rationalization processes may lead individuals to adjust their assessments of past attitudes and behaviors retroactively to tally with current attitudes and behaviors (cf. Finkel 1985; Finkel and Muller 1998).

\section{Analysis}

This article examines the nexus between association membership and political involvement based on one form of political involvement, namely frequency of participation in political discussions. Generally speaking, political discussions are regarded as an alternative index of interest in politics (or psychological political involvement), interest in politics being defined as " [...] the degree to which politics arouses a citizen's curiosity" (van Deth 1990:278) or as "attentiveness to politics" (Zaller 1992:18) (cf. e.g. van Deth and Elff 2001). ${ }^{7}$ It is assumed for our purposes that people who often take part in political discussions often engage in more sophisticated forms of political participation as well. Hence, psychological political involvement in general and an interest in politics and participation in political discussions in particular are also viewed as preliminaries to or as indicating a personal propensity for actual political activity (Campbell et al. 1960; Verba et al. 1995).

The following question was posed in this study to obtain data on frequency of participation in discussions of political subject-matter:

How often would you say you discuss political matters with others? Often, sometimes, seldom or never?

\footnotetext{
${ }^{7}$ Participation in political discussions is sometimes regarded and conceptualized as a form of political participation in and of itself (e.g. in Ulbig and Funk 1999:270). For an in-depth discussion of the concept see Topf (1995).
} 
In addition to participation in political discussions in general, respondents were asked on the written questionnaire (hence the lower numbers than for frequency of participation in political discussions in general) how often and in which social contexts (or with which groups of people) they engaged in political discussions:

How often do you discuss political matters when you are with the following groups of people: friends, family, neighbors, co-workers, fellow students, other people from associations/organizations of which you are a member? Often, sometimes, seldom or never?

As shown in Table 1, politics is discussed chiefly in the family and among friends. Over $60 \%$ of those surveyed at least sometimes discuss politics in these contexts. A little over half do so at work and a little over $40 \%$ with fellow members of associations. The neighborhood is, in contrast, of minor importance as an arena for political discussions. Roughly $80 \%$ never or rarely discuss politics with neighbors, and only a bit more than $2 \%$ do so often.

Table 1: Frequency of participation in political discussions in certain social contexts

\begin{tabular}{lcccccc}
\multicolumn{7}{c}{ (in percent of respondents) $^{8}$} \\
\hline Political Discussions & Never & Seldom & Sometimes & Often & Mean & $\mathrm{N}$ \\
& $(0)$ & $(0.33)$ & $(0.67)$ & $(1)$ & & \\
\hline In general & 6.60 & 30.05 & 30.15 & 33.19 & 0.63 & 2,145 \\
\hline In the family & 8.32 & 27.35 & 43.53 & 20.80 & 0.59 & 1,606 \\
With friends & 7.29 & 29.70 & 47.10 & 15.91 & 0.57 & 1,613 \\
With co-workers or fellow students & 15.10 & 30.06 & 42.13 & 12.70 & 0.51 & 1,090 \\
With other association members & 22.48 & 35.97 & 32.24 & 9.31 & 0.43 & 1,189 \\
With neighbors & 37.37 & 42.45 & 17.94 & 2.23 & 0.28 & 1,555 \\
\hline
\end{tabular}

Source: WNAP, weighted figures

The different variables regarding participation in political discussions are not all considered separately in the following. This study focuses on the analysis of political discussions outside of associations. The object is to attempt a general empirical explication of the frequency of participation in political discussions. Furthermore, the responses regarding political discussions in the family, with friends, with co-workers and fellow students, and with neighbors

\footnotetext{
${ }^{8}$ The survey sample was taken using a random-random method: To begin with, addresses were drawn at random from the Swiss telephone directory. Then an interviewee was randomly selected from among the members of each household. Given the greater probability of selecting people who live alone than those who live in a larger household, our descriptive statistics are weighted according to household size (though there is no such weighting in the "causal analyses").
} 
von Erlach: Politicization in Associations

are condensed into, and analyzed under, a single index: average participation in discussions outside of associations.

Table 2: Comparison between non-members, passive and active members: means for frequency of participation in political discussions

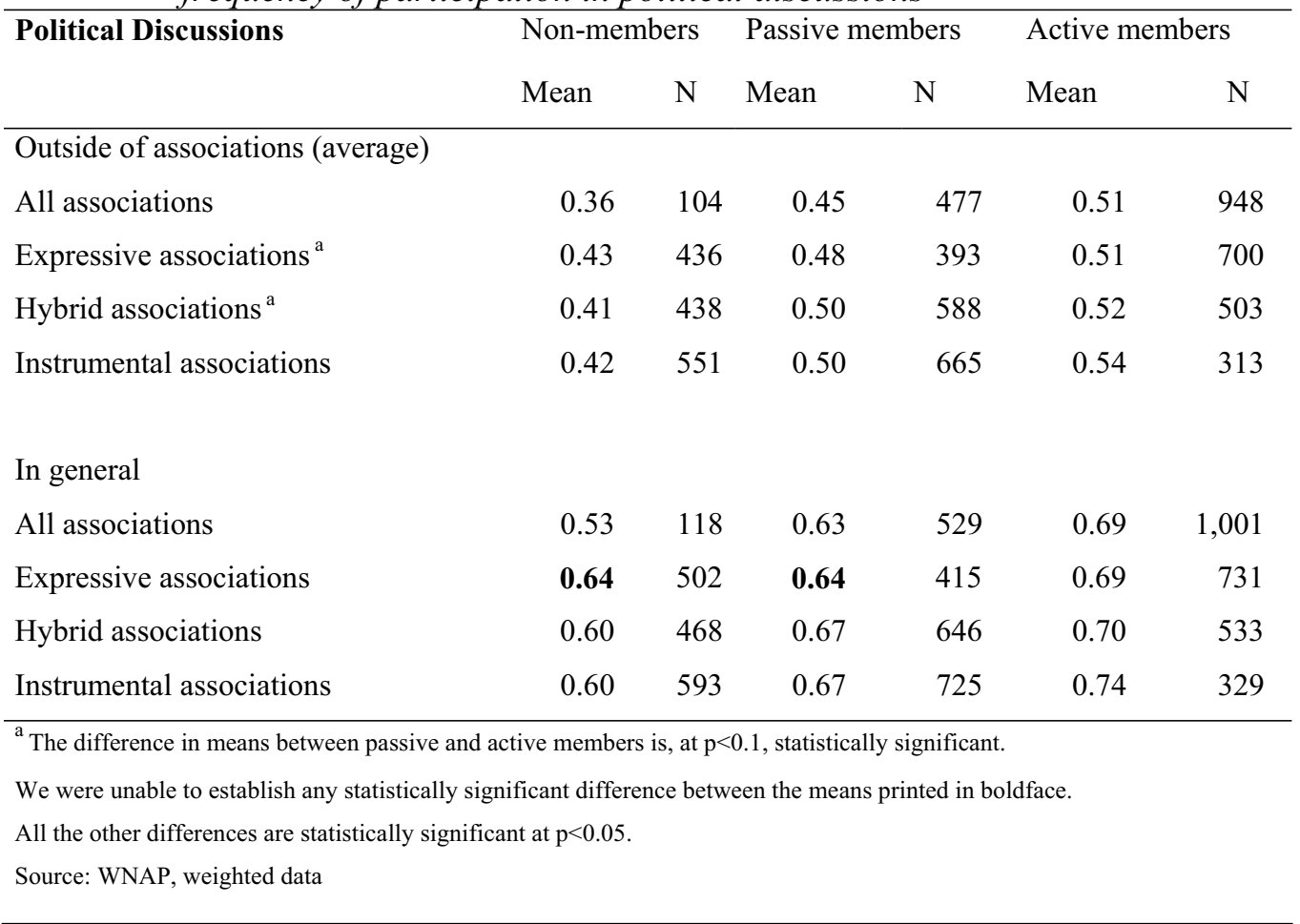

Table 2 shows that association members in fact participate in political discussions more frequently than individuals who are not involved in any voluntary organizations. ${ }^{9}$ Likewise, active members discuss politics more often than passive ones. The differences are discernible regardless of the type of association in question (expressive, hybrid or instrumental) (only between non-

\footnotetext{
${ }^{9}$ The percentage of non-members, over $7 \%$, is at least $10 \%$ lower than in other surveys (e.g. the Third Wave of the World Values Survey) on the Swiss resident population's involvement in associations (see overviews in Freitag 2001: 96ff; Gabriel et al. 2002:44). This divergence from other data sources may be due to a kind of self-selection by association members willing to take part in the survey used here. On the other hand, it may be objected that the series of questions we used here to determine membership in voluntary organizations is exceedingly detailed and therefore more liable to reveal actual association memberships through the survey. For one thing, the list used in the WNAP survey to determine association involvement is very long, with 34 categories of voluntary organizations to choose from (the World Value Survey, in contrast, only asks about nine categories). The advantage of the longer list is that it reminds respondents in an interview situation of a wider range of (especially passive) association memberships (Baumgartner and Walker 1988; Goul Andersen 1996; Erlach 2002; Geurts and Morales 2003). Secondly, we asked not only about membership as such, but also about participation in association activities, donations to and volunteer work for associations, which likewise contributes to higher overall (surveyed) membership figures (Geurts and Morales 2003).
} 
members and passive members of expressive associations can we find no statistically significant difference in mean for participation in political discussions in general). We have calculated various multivariate regressions to determine the extent to which the differences in mean are actually attributable to politicization in associations.

Table 3 presents three empirical models to explain average frequency of participation in political discussions outside of associations. The first model examines the effects of diverse aspects of association membership for which a connection with political discussions can be theoretically derived without including control variables through OLS regression. The adjusted R-squared of 0.12 indicates that membership in associations may explain at least part of the variance in frequency of participation in political discussions outside of associations. By far the greatest positive effect is shown for the exercise of skills in associations. This finding would seem to corroborate the hypothesis that voluntary organizations have a politicizing effect because they afford opportunities to cultivate organizational and communication skills that facilitate political involvement (cf. Verba and Nie 1972; Verba et al. 1995).

We note other statistically significant effects for active membership in hybrid and instrumental, but not for active membership in expressive voluntary organizations. So politicization occurs chiefly in associations which, given their substantive orientation, tend more often to represent special interests in the political decision-making process (e.g. economic associations, organizations representing social movements but also social-services associations) than in ones that tend to do so more seldom (e.g. sports clubs, choirs and other hobby clubs). This interpretation is not undermined by the negative correlation between ignorance of the political opinions of other association members and frequency of participation in political discussions outside the associational context. In all likelihood, people who are unaware of the political views of their fellow association members hardly ever, if at all, talk to them about politics. Hence, a modicum of political communication within an association seems to be a prerequisite for association members to be animated by their membership to greater political involvement.

There is, moreover, empirical evidence for the hypothesis of a negative correlation between conflict avoidance and participation in political discussions: association members who do not argue with their fellow members talk relatively little about politics in other social contexts. On the other hand, we were unable to find any confirmation of the cross pressures hypothesis. On the contrary, association members who, in the model without controls for social background, are not confronted in associations with divergent political views discuss politics even less than those subjected to cross pressures in associations. In the absence of any significant correlation, there is no evidence that associational integration and investing time in social participation are especially conducive to politicization in associations.

The results of the first model should not be taken entirely at face value, as this model disregards the fact that the correlations found are in some cases not at all due to various aspects of association membership, but to social background variables that influence both the impact of association variables 
von Erlach: Politicization in Associations

and the frequency of participation in political discussions. In certain circumstances the significant effects in this sense reflect rather the selfselection than socialization effects of association membership on political involvement.

The only independent variables allowed for in the second model in Table 3 are indices of social background (e.g. age, sex, education, social integration and teenage politicization). Although this model covers only a few more variables, its adjusted R-squared of 0.37 is substantially higher than the association model. Social background would therefore seem to be of greater import in explaining the frequency of participation in political discussions than association membership.

The positive impact of education on political discussions underscores the fact that human capital is a key determinant of political involvement. A statistically significant and relatively strong positive correlation also obtains between integration in one's neighborhood and participation in political discussions. Other important positive influences are age and politicization during youth. Furthermore, on average men seem to discuss politics somewhat more often than women (though this correlation is markedly less relevant than the others). These findings are important to the questions addressed in this study insofar as age, sex and education are variables often used to explain membership in associations (Bühlmann and Freitag 2004). In other words, these variables are in certain circumstances responsible for the positive effect of skills in associations and active membership in hybrid and instrumental associations on frequency of participation in political discussions outside of associations.

The social background model to explain participation in political discussions also identifies variables that have a negative influence on the variable we seek to elucidate. In accordance with our theoretical predictions, not only conflict avoidance in associations, but also conflict avoidance in general, seems to reduce the frequency of participation in political discussions. In contrast to the association model, the social background model tends to bear out the cross pressures hypothesis, pointing up the negative effects of the average number of networks with heavy cross pressures. The model also shows that those who hardly ever take part in political discussions can give but scant information about the political opinions of other network members.

The third model in Table 3 combines the variables of the association and social background models. The substance and significance of the effects of social background variables remain by and large stable in this model. Only the significance of conflict avoidance outside of associations disappears ${ }^{10}$. The only statistically significant effects under this combined model, however, are those of exercising skills and conflict avoidance in associations. Accordingly, it may be inferred that the effects of active membership in hybrid and instrumental associations, in particular, revealed in the association model are

${ }^{10}$ Multicollinearity can be ruled out as a possible cause of the decrease in significance. Multicollinearity is not an issue in any of the models presented here, for that matter: the values of the variance-inflation factor in each case lie well under the critical threshold of 4 (cf. Fox 1991). 
World Political Science Review Vol. 2 [2006], No. 1, Article 3

the effects of self-selection. Likewise, the correlation between skills in associations and political discussions is partly due to self-selection effects, since the combined model substantially diminishes the magnitude of the effects of skills. Part of the influence of the exercise of organizational and communication skills in associations on the frequency of participation in political discussions is probably due to the fact that the exercise of skills depends on education.

Table 3: Predictors of frequency of participation in political discussions outside of

\begin{tabular}{|c|c|c|c|c|c|c|c|c|c|}
\hline & $\mathrm{B}$ & Beta & Sig. & $\mathrm{B}$ & Beta & Sig. & $\mathrm{B}$ & Beta & Sig \\
\hline Constants & 0.55 & & $* * *$ & 0.01 & & & 0.06 & & \\
\hline Active membership: & & & & & & & & & \\
\hline Expressive associations & 0.00 & 0.00 & & & & & 0.01 & 0.03 & \\
\hline Hybrid associations & $\mathbf{0 . 0 3}$ & 0.07 & $* * *$ & & & & 0.00 & 0.01 & \\
\hline Instrumental associations & 0.04 & 0.07 & $* * *$ & & & & 0.01 & 0.01 & \\
\hline Time spent on social participation & -0.01 & -0.01 & & & & & -0.01 & -0.02 & \\
\hline Skills in associations & 0.12 & 0.10 & $* * *$ & & & & 0.05 & 0.05 & * \\
\hline Integration (association) & -0.01 & -0.02 & & & & & -0.03 & -0.05 & \\
\hline Conflict avoidance in associations & -0.08 & -0.14 & $* * *$ & & & & -0.06 & -0.10 & $* * *$ \\
\hline No cross pressures in associations & -0.06 & -0.06 & $* *$ & & & & -0.02 & -0.02 & \\
\hline $\begin{array}{l}\text { Heavy cross pressures in } \\
\text { associations }\end{array}$ & -0.03 & -0.03 & & & & & 0.00 & 0.00 & \\
\hline $\begin{array}{l}\text { No knowledge of others' political } \\
\text { opinions (in associations) }\end{array}$ & -0.09 & -0.20 & $* * *$ & & & & 0.02 & 0.04 & \\
\hline Age (log.) & & & & 0.16 & 0.12 & $* * *$ & 0.16 & 0.12 & $* * *$ \\
\hline $\operatorname{Sex}(\mathrm{m})$ & & & & $\mathbf{0 . 0 3}$ & 0.06 & $* * *$ & 0.02 & 0.04 & $*$ \\
\hline Education & & & & 0.28 & 0.15 & $* * *$ & 0.25 & 0.13 & $* * *$ \\
\hline Skills at work & & & & 0.02 & 0.02 & & 0.01 & 0.02 & \\
\hline Married & & & & 0.00 & 0.01 & & -0.00 & -0.00 & \\
\hline Integration (work) & & & & -0.03 & -0.04 & & -0.02 & -0.04 & \\
\hline Integration (neighborhood) & & & & 0.13 & 0.15 & $* * *$ & 0.12 & 0.13 & $* * *$ \\
\hline Duration of local residence & & & & 0.01 & 0.03 & & 0.02 & 0.03 & \\
\hline Conflict avoidance & & & & -0.05 & -0.06 & $* *$ & -0.03 & -0.03 & \\
\hline Number of networks: & & & & & & & & & \\
\hline $\begin{array}{l}\text { With no cross pressures (not } \\
\text { including associations) }\end{array}$ & & & & -0.04 & -0.04 & & -0.02 & -0.02 & \\
\hline Heavy cross pressures (not including & & & & & 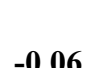 & $* * *$ & -0.08 & . & $* * *$ \\
\hline associations) & & & & - 30 & -0.06 & & -0.08 & $\begin{array}{l}-0.07 \\
-0.40\end{array}$ & 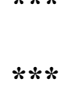 \\
\hline $\begin{array}{l}\text { views (not including associations) } \\
\text { Teenage politicization }\end{array}$ & & & & $\begin{array}{r}-0.30 \\
0.16\end{array}$ & $\begin{array}{c}-0.38 \\
0.25\end{array}$ & $* * *$ & $\begin{array}{r}-0.31 \\
0.16\end{array}$ & $\begin{array}{r}-0.40 \\
0.24\end{array}$ & $* * *$ \\
\hline Adjusted R-squared & 0.12 & & & 0.37 & & & 0.37 & & \\
\hline $\mathrm{N}$ & 1'375 & & & $1 ' 227$ & & & 1'144 & & \\
\hline
\end{tabular}


von Erlach: Politicization in Associations

Another model was employed to test the robustness of the analytical findings. It examines the extent to which association membership has an influence on frequent participation in political discussions. ${ }^{11}$

Table 4: Predictors of frequent participation in political discussions in general (binomial logistic regressions)

\begin{tabular}{|c|c|c|c|}
\hline & B & $\operatorname{Exp}(B)$ & Sig. \\
\hline Constants & -5.83 & 0.00 & $* * *$ \\
\hline \multicolumn{4}{|l|}{ Active membership: } \\
\hline Expressive association & -0.05 & 0.95 & \\
\hline Hybrid association & -0.22 & 0.80 & \\
\hline Instrumental association & 0.11 & 1.12 & \\
\hline Time invested in social participation & 0.03 & 1.03 & \\
\hline Skills in associations & 1.10 & 3.00 & $* *$ \\
\hline Integration (association) & -0.39 & 0.68 & \\
\hline Conflict avoidance in associations & -0.86 & 0.42 & $* * *$ \\
\hline No cross pressures in associations & 0.69 & 2.00 & * \\
\hline Heavy cross pressures in associations & 0.86 & 2.36 & $* * * *$ \\
\hline No knowledge of others' political opinions & 0.26 & 1.29 & \\
\hline Age (log.) & 2.66 & 14.30 & $* * *$ \\
\hline $\operatorname{Sex}(m)$ & -0.01 & 0.99 & \\
\hline Education & 2.28 & 9.77 & $* * * *$ \\
\hline Skills at work & 0.95 & 2.58 & $* * * *$ \\
\hline Married & -0.27 & 0.76 & * \\
\hline Integration (work) & -0.81 & 0.45 & $* * *$ \\
\hline Integration (neighborhood) & 0.07 & 1.07 & \\
\hline Duration of local residence & 0.19 & 1.21 & \\
\hline Conflict avoidance & -0.51 & 0.60 & \\
\hline \multicolumn{4}{|l|}{ Number of networks: } \\
\hline $\begin{array}{l}\text { With no cross pressures (not including } \\
\text { associations) }\end{array}$ & -0.48 & 0.62 & \\
\hline $\begin{array}{l}\text { With heavy cross pressures (not including } \\
\text { associations) }\end{array}$ & -0.25 & 0.78 & \\
\hline $\begin{array}{l}\text { With no knowledge of others' political } \\
\text { opinions (not including associations) }\end{array}$ & -1.72 & 0.18 & $* * *$ \\
\hline Teenage politicization & 1.69 & 5.42 & $* * *$ \\
\hline \multicolumn{4}{|l|}{ Pseudo R-squared } \\
\hline Cox and Snell & 0.20 & & \\
\hline Nagelkerke & 0.27 & & \\
\hline $\mathrm{N}$ & $1 ' 215$ & & \\
\hline \multicolumn{4}{|l|}{$* \mathrm{p}<0.1 ; * * \mathrm{p}<0.05 ; * * * \mathrm{p}<0.01$} \\
\hline Source: WNAP & & & \\
\hline
\end{tabular}

The findings of our analysis of the determining factors of frequent participation in political discussions coincide in large measure with the findings of our analysis of average frequency of participation in political

${ }^{11}$ This variable is based on responses to the general question as to frequency of participation in political discussions. It distinguishes between individuals who often take part in political discussions (value 1) and those who sometimes, seldom or never do so (value 0 ). 
discussions outside of associations. It emerges once again that the politicizing effect of associations derives above all from the exercise of skills. Active membership in voluntary organizations per se, investing time in social participation, and integration in associations are not decisive in determining whether or not an association member often takes part in political discussions. Also replicable are the findings that non-engagement in conflicts has a negative influence, and cross pressures in associations have no influence, on participation in political discussions. According to our analysis, association members who have marked differences of political opinion with their fellow members in an association take part in political discussions with above-average frequency. The same goes for association members who are not confronted with any differences of political opinion. The latter correlation is but of low significance, however, and of limited strength, as it contradicts the finding in the first model in Table 3.

The social background variables also exhibit correlations with the explanatory model for participation in political discussions outside of associations. Significant positive effects can again be shown for age, education and politicization during youth, and negative effects for the average number of networks with no knowledge of other network members' political opinions. A significant positive correlation re-emerges for the exercise of skills at work, underscoring the importance of human capital as a factor favoring political involvement. But it appears that social integration in the form of inclusion in networks at work and cohabitation in a steady couple tends to reduce the frequency of participation in political discussions.

\section{Conclusions}

Both in democracy theory and political behavior research, Tocqueville's contention that associations serve as schools of democracy has enjoyed a veritable peak in popularity since the mid-1990s. Associations are expected to make a substantial contribution to politicizing the populace, among other things, ensuring that more individuals will become active citizens (cf. e.g. Warren 2001). There is, to be sure, no dearth of empirical studies showing that, on average, members of voluntary organizations show a greater interest in politics and participate politically more often than non-members (cf. Verba et al. 1995; van Deth 1997; Stolle and Rochon 1998; van Deth 2001; Gabriel et al. 2002). However, since many studies of association membership make use of relatively rough indicators, it is not possible to specify the mechanisms responsible for this phenomenon. In the absence of simultaneous tests, many studies leave unanswered the question as to whether the politicization of association members is more the upshot of the effects of integration, socialization or education. Nor can one entirely rule out the possibility that the observed differences in political involvement are simply due to the fact that individuals who are interested and prepared to participate in politics are more inclined to join an association than those who are politically apathetic.

The question of the nexus between association membership and political involvement is examined here based on one manifestation of the latter: the 
frequency of participation in political discussions. Our study looks at various aspects of association membership which, based on theoretical considerations, may be expected to have an influence on participation in discussions of political matters: viz. active membership in different types of associations, time spent on association activities, the exercise of organizational and communication skills in associational contexts, integration in associations, carrying out conflicts within associations and membership-related cross pressures. The respondents' average frequency of participation in political discussions outside of associations and frequent participation in political discussions in general serve in this study as dependent variables.

The main findings of the present study can be summed up as follows: First of all, it can be shown that association members (especially active ones) are more political involved than non-members. In the second place, we found that associations have a politicizing effect primarily on members who take advantage of opportunities to learn or cultivate organizational and communication skills within the framework of association activities. Thirdly, the negative correlation between conflict avoidance in associations and frequency of participation in political discussions suggests that associations can promote political involvement by helping their members cope with conflict. Finally, it should be borne in mind that differences in political involvement between association members and nonmembers are probably attributable in large measure to self-selection effects. Controlling for social background variables - above all education levels and early political socialization - negates the significance of the influence of active membership in instrumental associations and substantially reduces the magnitude of the effects of the exercise of skills. Furthermore, neither associational integration nor time invested in social participation, both of which ought to show a positive correlation with membership-related socialization, has an influence on participation in political discussions.

The analyses submitted here serve the micro-grounding of theories regarding the influence of voluntary organizations on the political behavior of their members. However, they shed light on only one form of political involvement. In particular, it remains to be shown whether connections between membership in associations and other forms of psychological political involvement or political participation can be explained along similar lines. 


\section{Appendix: Operationalization of the various concepts}

All the scales are designed to yield values between 0 and 1. This data transformation simplifies interpretation of the results since the coefficients can be viewed as the maximum effects of the independent on the dependent variables.

\section{Political discussions in associations:}

Question: How often do you discuss political matters when you are together with the following groups of people: With other members of your association?

Four response categories from "never" (0) to "often" (1).

Political discussions outside of associations:

Question: How often do you discuss political matters when you are together with the following groups of people: Friends, family, neighbors, co-workers and fellow students?

Four response categories from "never" (0) to "often" (1).

We calculated the average frequency of participation in political discussions in the existing social contexts.

\section{Political discussions in general:}

Question: How often would you say you discuss political matters with others?

Four response categories from "never" (0) to "often" (1).

\section{Degree of involvement in associations}

Question: Here is a list of clubs, associations and other organizations. We'd like to ask you a few questions about your involvement in each type of organization: check the corresponding box if you

A. Are a member of such an organization

B. Have taken part in an event or activity of this organization at any time in the past 12 months

D. Have worked in an honorary capacity (i.e. unpaid) for this organization at any time in the past 12 months.

We distinguished between the following three categories of association:

Expressive associations:

Sports clubs, youth clubs, cultural associations (e.g. choirs or amateur theater groups), local history societies (counted as cultural organizations), hobby breeders' associations, other hobby clubs, investment clubs (investors' societies), veterans' organizations ${ }^{12}$.

Hybrid associations:

\footnotetext{
${ }^{12}$ Veterans' organizations in Switzerland are predominantly "alumni" associations whose main object is to arrange social functions for veterans to get together and keep in touch with one another.
} 
von Erlach: Politicization in Associations

Charitable institutions or benevolent societies, associations in the public health sector (including self-help groups and patients' organizations), handicapped organizations, pensioners' organizations, lodges and service clubs (e.g. Rotary), parents' associations, religious and church organizations, foreigners' associations, women's groups, volunteer firefighters (and similar organizations).

Instrumental associations:

Environmental organizations, animal protection organizations, the peace movement, human rights organizations, consumer protection organizations, labor unions, trade and industrial associations and employers' organizations, professional associations (including officers' and non-commissioned officers' clubs and academic organizations) and farmers' associations.

A dummy variable was formed to measure active membership in each association category $(1=$ yes answer to question part B or D).

Time invested in association activities:

Question: In the past month how much time have you spent on all these activities put together, i.e. in associations, in volunteer work that involves taking care of others and in other [informal] groups you are in touch with on a regular basis?

Response categories: less than one hour (value 0), 1 to 4 hours (0.25), 5 to 10 hours (0.5), 11 to 20 hours (0.75) and more than 20 hours (1).

Given the relatively broad response categories, as well as the fact that the question refers not only to association activities, but also to activities in informal groups and care-related volunteer work, this variable can only be interpreted as a proxy for time spent on voluntary organizations.

Organizational and communication skills:

Question: When you consider your activities in associations or organizations, how often do you take part in decision-making processes at meetings? How often do you plan or run a meeting? How often do you give speeches or prepare speeches to be given at meetings? How often do you write texts of several pages, apart from personal correspondence?

The response categories for each question are: Never or almost never (0), a few times per year (0.33), per month (0.67) or per week (1).

An additive index was formed out of the four items.

Integration in associations:

Question: Some people have a great deal of contact with fellow members of their association. Others have little contact. What about you? How often do you do the following things with other members of your association:

Help one another solve practical problems? Visit one another?

Talk about the association's problems or goals?

Four response categories for each from "never" (0) to "often" (1). 


\section{Conflict avoidance in associations:}

Question: Some people have a great deal of contact with fellow members of their association. Others have little contact. What about you? How often do you do the following things with other members of your association (or co-workers or neighbors): Disagree or argue?

Four response categories for each from "never" (0) to "often" (1).

The signs of the responses were reversed for the index ( 1 - original value).

Networks were added and divided by the number of existing contexts.

\section{Cross pressures:}

Question: When you consider the following groups of people, do you basically agree or disagree with them on political issues: Other members of your association?

Response categories: I don't know. We agree. Sometimes we disagree. We fundamentally disagree.

A dummy variable was formed for each response category (reference category $=$ sometimes we disagree).

Age:

Question: Would you please state your age? The logarithmic age was taken as the variable.

Sex:

Dummy variable $(0=$ female, $1=$ male $)$

\section{Education:}

Question: All in all, how many years of full-time education have you had, including primary school?

Response category: number of years.

Organizational and communication skills (skills at work):

Question: As part of your work, how often do you take part in decision-making processes at meetings? How often do you plan or run a meeting? How often do you give speeches or prepare speeches to be given at meetings? How often do you write texts of several pages, apart from personal correspondence?

The response categories for each are: Never or almost never (0), a few times per year (0.33), per month (0.67) or per week (1).

An additive index was formed comprising the four items.

\section{Marital status:}

Question: What is your marital status? Married, cohabiting, single, divorced or widowed?

A dummy variable was formed (married and cohabiting were equated $=1$; single, divorced, widowed $=0$ ). 
von Erlach: Politicization in Associations

Integration at work:

The data were collected using a question similar to the one on integration in associations and the variable was operationalized accordingly.

Integration in one's neighborhood:

The data were collected using a question similar to the one on integration in associations and the variable was operationalized accordingly.

\section{Local residence:}

Question: How long have you been living in (place of residence)?

Response categories from "two years or less" (0) to "11 years or more" (1).

Conflict avoidance (outside of associations):

Question: Some people have a great deal of contact with their co-workers (neighbors). Others have little contact. What about you? How often do you do the following things with your co-workers (neighbors): Disagree or argue?

Four response categories for each from "never" (0) to "often" (1).

The signs of the responses were reversed for the index ( 1 - original value).

The conflict avoidance tendencies in both networks were added and divided by the number of existing contexts.

Average number of contexts with cross pressures (not including associations):

A dummy variable was formed for each response category.

Question: When you consider the following groups of people, do you basically agree or disagree with them on political issues? Friends, family, neighbors, coworkers, fellow students?

Response categories: We agree. Sometimes we disagree. We fundamentally disagree. I couldn't say.

The dummy variables were added and divided by the number of existing contexts.

\section{Early political socialization:}

Political socialization is measured in terms of political discussions held in the family during one's youth.

Question: Earlier, when you were still living at home [clearer: with your parents!], how often did your family discuss politics at home?

Four response categories from "never" (0) to "often" (1). 


\section{Bibliography}

ARMINGEON, KLAUS (2004). "Political participation and associational involvement." ESF Network on Citizenship, Involvement, Democracy, Bern.

ARMingeOn, KlAUS and EMANUEL VON ERLACH (2000): Arbeit, Nachbarschaft, Vereine und Politik. Fragebogen der schriftlichen Befragung im Rahmen des NF-Projekts "Soziale Integration und politische Partizipation".

Ayala, LouIs J. (2000). "Trained for Democracy: The Differing Effects of Voluntary and Involuntary Organizations on Political Participation." Political Research Quarterly 51 (1):99-115.

Bartolini, Stefano and Peter MAIR (1990). Identity, Competition, and Electoral Availability. The stabilization of European electorates 1885-1985. Cambridge: Cambridge University Press.

BAUMGARTNER, FrANK R. and JACK L. WALKER (1988). "Survey Research and Membership in Voluntary Associations." American Journal of Political Science 32 (4):908-928.

Booth, John A. and PAtricia BAyer Richard (1998). "Civil Society, Political Capital, and Democratization in Central America." The Journal of Politics 60 (3):780-800.

Bowler, Shaun, Todd Donovan and Robert Hanneman (2003). "Art for Democracy's Sake? Group Membership and Political Engagement in Europe." The Journal of Politics 65 (4):1111-1129.

Brady, Henry E., Sidney Verba and Kay Lehman Scholzman (1995). "Beyond SES: A Resource Model of Political Participation." American Political Science Review 89 (2):271-294.

BÜHLManN, MarC And Markus Freitag (2004). "Individuelle und kontextuelle Determinanten der Teilhabe an Sozialkapital. Eine Mehrebenenanalyse zu den Bedingungen des Engagements in Freiwilligenorganisationen." Kölner Zeitschrift für Soziologie und Sozialpsychologie 56 (2):326-349.

Campbell, Agnus, Philip E. Converse, Warren E. Miller and Donald E. StOKES (1960). The American Voter. New York: John Wiley \& Sons.

Coleman, James S. (1990). Foundations of Social Theory. Cambridge, Mass.: Belknap Press.

ERICKSON, BONNIE H. and T.A. NOSANCHUCK (1990). "How an Apolitical Association Politicizes." Canadian Review of Sociology and Anthropology 27 (2):206-219.

ERLACH, EMANUEL VON (2002). "Measures of Associational Involvement. The Impact of Different Interview Techniques, Question Wordings and Missing Values." Institute for Political Science, University of Bern, Bern.

Evans, Sara M. and Harry C. Boyte (1992). Free Spaces: The Source of Democratic Change in America. Chicago: Chicago University Press. 
von Erlach: Politicization in Associations

Finkel, STEVen E. (1985). "Reciprocal Effects of Participation and Political Efficacy: A Panel Analysis." American Journal of Political Science 29 (4):891913.

Finkel, Steven E. and Edward N. Muller (1998). "Rational Choice and the Dynamics of Collective Political Action: Evaluating Alternative Models with Panel Data." American Political Science Review 92 (1):37-49.

Fox, JoHn (1991). Regression Diagnostics. Quantitative Applications in the Social Sciences Series No. 79. Thousand Oaks: Sage Publications.

FreitaG, MARKus (2001). "Das soziale Kapital in der Schweiz: vergleichende Einschätzungen $\mathrm{zu}$ Aspekten des sozialen Vertrauens und der sozialen Einbindung." Schweizerische Zeitschrift für Politikwissenschaft 7 (4):87-117.

GABriel, Oscar W., VOLKER KUnZ, Sigrid RossteutsCher and JAN W. VAN DETH (2002). Sozialkapital und Demokratie. Zivilgesellschaftliche Ressourcen im Vergleich. Vienna: WUV.

GeUrts, Peter and LAURA Morales (2003). "Associational Involvement." Chapter draft. ESF Network on Citizenship, Involvement, Democracy.

GORDON, StaCy B. and Gary M. SEgura (1997). "Cross-National Variation in the Political Sophistication of Individuals: Capability or Choice?" The Journal of Politics 59 (1):126-147.

Goul ANDERSEN, JøRGEN (1996). "Membership and Participation in Scandinavia, in a Comparative Perspective." Department of Economics, Politics and Public Administration. Aalborg University, Aalborg.

Gundelach, Peter and LARS TORPe (1997). "Social Reflexivity, Democracy and New Types of Citizen Involvement in Denmark." In Jan van Deth (ed.) Private Groups and Public Life. Social participation, voluntary associations and political involvement in representative democracies. London and New York: Routledge. 47-63.

HANKS, MichAEL (1981). "Youth, Voluntary Associations and Political Socialization." Social Forces 60 (1):211-223.

HANKS, Michael and BRUCE K. ECKLAND (1978). "Adult Voluntary Associations and Adolescent Socialization." The Sociological Quarterly 19 (Summer):461486.

Huckfeldt, Robert, Paul E. Johnson and John Sprague (2002). "Political Environments, Political Dynamics, and the Survival of Disagreement." The Journal of Politics 64 (1):1-21.

Huckfeldt, Robert, Jeannette Morehouse and Tracy Olson (2001). "Disagreement, Ambivalence, and Engagement: The Political Consequences of Heterogeneous Networks." Annual Meeting of American Political Science Association, San Francisco, August 29-September 2, 2001

IKEDA, KEN'ICHI (2002). "Social Capital and Social Communication in Japan: Political Participation and Tolerance." CSD Papers 02-05. Center for Democratic Studies, University of California, Irvine CA.

JACOBY, ARTHUR P. (1965). "Some Correlates of Instrumental and Expressive Orientation to Associational Membership." Social Inquiry 35:191-206.

JACOBY, ARTHUR P. and NiCOLAS BABCHUK (1963). "Instrumental and Expressive Voluntary Association.” Sociology and Social Research 47:461-453. 
JoYe, DOMONIQUe and ANNIE LAURANT (1997). "Associative and political participation in Switzerland and France." In Jan W. Van Deth (ed.) Private Groups and Public Life. Social participation, voluntary associations and political involvement in representative democracies. London and New York: Routledge. 163-182.

KLESNER, JOSEPH L. (2002). "Social Capital and Political Participation in Latin America." Annual Meeting of American Political Science Association, Boston, August 28-September 1, 2002

KUNZ, VOLKER and OSCAR W. GABRIEL (2000). "Soziale Integration und politische Partizipation. Das Konzept des Sozialkapitals - ein brauchbarer Ansatz zur Erklärung politischer Partizipation?" In Ulrich Druwe, Steffen Kühnel and Volker Kunz (eds.) Kontext, Akteur und strategische Interaktion. Opladen: Leske und Budrich. 47-74.

La Due LaKe, Roland and Robert Huckfeldt (1998). "Social Capital, Social Networks, and Political Participation." Political Psychology 19 (No. 3):567-584.

LEIGHLEY, JAN (1996). "Group Membership and the Mobilization of Political Participation.” The Journal of Politics 58 (2):447-463.

LiPSET, SEYMOUR MARTIN and STEIN RoKKAn (1967). "Cleavage Structures, Party Systems, and Voter Alignments: An Introduction.” In Seymour Martin Lipset and Stein Rokkan (eds.) Party Systems and Voter Alignments: Cross National Perspectives. New York: The Free Press. 1-64.

LONDON, BRUCE (1975). "Racial Differences in Political Participation: It's Not Simply a Matter of Black or White.” Social Science Quarterly 57:274-286.

MACCOBY, HERBERT (1958). "The differential political activity of participants in voluntary associations." American Sociological Review 23 (5):524-532.

MCMILleR, DARRYL L. (2000). "Race, Associational Involvement, and Political Participation." Race \& Society 2 (1):83-95.

Miller, Melissa K. (2001). "Organized Groups and Political Participation: Varieties of Social Influence." Annual Meeting of American Political Science Association, San Francisco, August 29-September 2, 2001

Milner, Henry (2001). Civic Literacy: How Informed Citizens Make Democracy Work. Hanover, NH: University Press of England.

Moyser, GeOrge and PARRY GERAINT (1997). "Voluntary associations and democratic participation in Britain." In Jan van Deth (ed.) Private Groups and Public Life. Social participation, voluntary associations and political involvement in representative democracies. London and New York: Routledge. 24-46.

MutZ, Diana C. (2002). "The Consequences of Cross-Cutting Networks for Political Participation." American Journal of Political Science 46 (4):838-855.

Newton, KenNeth (1997). "Social Capital and Democracy." American Behavioral Scientist 40 (5):575-586.

Nie, Norman , Bingham G. Powell and Kenneth Prewitt (1969a). "Social Structure and Political Participation: Developmental Relationships, Part 1." American Political Science Review 63 (2):361-378.

Nie, Norman , Bingham G. Powell and Kenneth Prewitt (1969b). "Social Structure and Political Participation: Developmental Relationships, Part 2." American Political Science Review 63 (3):808-832. 
von Erlach: Politicization in Associations

Olsen, MARVIN E. (1972). "Social Participation and Voting Turnout: A Multivariate Analysis." American Sociological Review 37:317-333.

Olsen, MARVIN E. (1974). "Interest Association Participation and Political Activity in the United States and Sweden." Journal of Voluntary Action Research 3:1732.

Parry, Geraint, George Moyser and Neil Day (1992). Political participation and democracy in Britain. Cambridge: Cambridge University Press.

Pettersen, Per Ant and Lawrence E. Rose (1996). "Participation in Local Politics in Norway: Some Do, Some Don't; Some Will, Some Won't." Political Behavior 18 (1):51-97.

POLLOK, PHILIP H. III (1982). "Organizations as Agents of Mobilization: How does Group Activity Affect Political Participation?" American Journal of Political Science 26 (3):485-503.

Putnam, Robert D. (1993a). Making Democracy Work. Civic Traditions in Modern Italy. Princeton: Princeton University Press.

Putnam, Robert D. (1993b). "The Prosperous Community: Social Capital and Public Life." The American Prospect (13 (Spring)).

PUTNAM, ROBERT D. (2000). Bowling alone. The collapse and revival of American community. New York: Simon and Schuster.

ROGERS, DAVID L. and GORDON L. BULTENA (1975). "Voluntary Associations and Political Equality: An Extension of Mobilization Theory." Journal in Voluntary Action Research 4:172-183.

Rogers, David L., Gordon L. Bultena and Ken H. Barb (1975). "Voluntary Association Membership and Political Participation. An Exploration of the Mobilization Hypothesis.” The Sociological Quarterly 16 (Summer):305-318.

ROKKAN, STEIN (1977). "Towards a Generalized Concept of Verzuiling: A Preliminary Note." Political Studies 25:563-570.

RothenBerG, LAWRENCE S. (1992). Linking Citizens to Government: Interest Group Politics at Common Cause. Cambridge: Cambridge University Press.

Seligson, AmBer L. (1999). "Civic Associations and Democratic Participation in Central America: A Test of the Putnam Thesis." Comparative Political Studies $32(3): 342-362$.

SteINER, JÜRG (1969). Bürger und Politik. Meisenheim am Glan: Verlag Anton Hain.

TeOrell, Jan (2003). "Linking Social Capital to Political Participation: Voluntary Associations and Networks of Recruitment in Sweden." Scandinavian Political Studies 26 (1):49-66.

TocQueville, AleXIS DE (1961 [1840]). De la démocratie en Amérique. Tome II. Paris: Gallimard.

TOPF, RICHARD (1995). "Beyond Electoral Participation." In Hans Dieter Klingemann and Dieter Fuchs (eds.) Citizens and the State. Oxford: Oxford University Press. 52-91.

Ulbig, Stacy G. and Carolyne L. FunK (1999). "Conflict Avoidance and Political Participation.” Political Behavior 21 (3):265-282.

VAN DETH, JAN W. (1990). "Interest in Politics." In M. Kent Jennings and Jan van Deth (eds.) Continuities in Political Action: A longitudinal Study of Political 
Orientations in Three Western Democracies. Berlin, New York: De Gruyter and Aldine. 275-312.

VAN DETH, JAN W. (1996). "Voluntary Associations and Political Participation.” In Oscar W. Gabriel and Jürgen W. Falter (eds.) Wahlen und politische Einstellungen in westlichen Demokratien. pp. 389-411 Frankfurt am Main: Lang.

VAN DETH, JAN W. (1997). "Introduction: Social involvement and democratic politics." In Jan W. van Deth (ed.) Private Groups and Public Life. Social participation, voluntary associations and political involvement in representative democracies. London and New York: Routledge. 1-23.

VAN Deth, Jan W. (2000). "Interesting but Irrelevant. Social Capital and the saliency of politics in Western Europe." European Journal of Political Research 37:115-147.

VAn Deth, JAN W. (2001). "The Proof of the Pudding: Social Capital, Democracy, and Citizenship." EUROESCO Conference "Social Capital: Interdisciplinary Perspectives", Exeter, United Kingdom, 15-20 September 2001

VAN DETH, JAN W. and MARTIN ElfF (2000). "Political Involvement and Apathy in Europe 1973-1998." Arbeitspapiere. Mannheimer Zentrum für Europäische Sozialforschung (MZES).

VAN Deth, Jan W. and Martin ElfF (2001). "Politicization and Political Interest in Europe: A Multi-Level Approach.” Arbeitspapiere. Mannheimer Zentrum für Europäische Sozialforschung (MZES).

Verba, Sidney and Norman H. Nie (1972). Participation in America. Political democracy and social equality. New York: Harper \& Row.

Verba, Sidney, Kay Lehman Schlozman and Henry E. Brady (1995). Voice and Equality. Civic Voluntarism in American Politics. Cambridge (MA.) and London: Harvard University Press.

WARren, Mark E. (2001). Democracy and Association. Princeton: Princeton University Press.

Wollebaek, Dag and Per Selle (2003). "Participation and Social Capital Formation: Norway in a Comparative Perspective." Scandinavian Political Studies 26 (1):67-91.

ZaLler, John R. (1992). The Nature and Origins of Mass Opinion. Cambridge: Cambridge University Press.

ZipP, JoHn F. and Joel SMith (1979). "The Structure of Electoral Participation." The American Journal of Sociology 85 (1):167-177. 
Politisation et associations volontaires: Une étude empirique du rapport entre l'affiliation organisationnelle et la participation à des discussions politiques

Cet article analyse le rapport entre l'affiliation organisationnelle et la participation aux discussions politiques. L'analyse descriptive montre que les membres des associations volontaires prennent plus souvent part aux discussions de contenu politique que les individus sans affiliations. Cependant, cette corrélation est seulement partiellement due aux effets de politisation de la vie associative. Elle diminue largement si on tient compte de l'éducation et la socialisation politique pendant l'adolescence. Tout de même, les associations volontaires peuvent stimuler l'engagement politique surtout en offrant aux membres des possibilités d'acquérir des compétences organisationnelles et des compétences de communication.

Emanuel von ERLACH, Swiss Federal Statistical Office, Espace de l'Europe 10, 2010 Neuchâtel, Switzerland. E-mail: emanuel.vonerlach@bfs.admin.ch

Emanuel von ERLACH has just finished his Ph. D. thesis on the impact of membership in associations on political engagement. He is currently working in the field of educational statistics at the Swiss Federal Statistical Office. 